\title{
センサ統合による無人ヘリコプター搭載型マッピングシステム
}

\section{Unmanned Helicopter borne 3D Mapping System based on Multi-Sensor Integration}

\author{
長井 正彦*・柴崎 亮介*・陳天恩* \\ 熊谷 秀夫**・水上慎太郎** \\ Masahiko NAGAI, Ryosuke SHIBASAKI, Tianen CHEN, \\ Hideo KUMAGAI and Sintaro MINAKAMI
}

\begin{abstract}
In this research, we propose an automatic 3D mapping system based on multi-sensor integration that is a combination of IMU (FOG), GPS, laser scanner and digital camera. An automatic mapping means that direct geo-referencing is achieved automatically without any ground control points, which accurately measures ground coordinate values. 3D model is reconstructed by laser scanner as 3D point cloud data, while texture is acquired by digital camera from the same platform simultaneously. The accurate trajectory of the platform with attitude changes is determined through the integration of GPS/IMU and digital camera. All the measurement tools are loaded on the unmanned helicopter, RPH2, which is made by Fuji Heavy Industries Ltd. A method of 3D mapping by integrating all the sensors from an unmanned helicopter is focused in this paper.
\end{abstract}

\section{1.はじめに}

3 次元 GIS, ナビゲーション, デジタルアーカイブ, シミュレーション，コンピュータゲーム等の多くの分 野で，実世界をより忠実かつ詳細に表現する 3 次元空 間情報の二ーズが広がっている(趙ら，2002）。3 次元 デー夕を取得する方法は，すでに多くの手法が実用化 され, さらに様々な新しい手法の研究が行われている。 近年の技術進歩と共に，デジタルカメラ，マルチスぺ クトルメーター, レーザスキャナ、レーザレンジファ インダー, GPS (全地球測位システム), IMU (慣性航 法装置）等の様々なセンサが開発・改良され，計測技 術やセンサの高精度化や小型化，低価格化は飛躍的に 進んでいる。

これらのセンサをうまく組み合わせることができれ ば，低価格で機動性が高く，しかも十分な精度を有す る 3 次元デー夕計測システムを構築できる可能性があ

* 東京大学空間情報科学研究センター

**多摩川精機(侏)

「写真測量とリモートセンシング」VOL. 44，NO. 6， 2005
る。しかしながら，現在利用されている 3 次元デー夕 取得システムは，ほとんどが比較的少数のセンサを用 いた「単独システム」であり, 今までの 3 次元計測手 法に扔いて精度をより向上させるためには，より高価 な高精度センサを利用するという方策をとっているた めに，計測センサが効果的に統合されてはいない。ま た，計測精度はセンサ個々が保有している精度に依存 し，センサ統合による精度向上やシステム全体の低価 格化の検討はなされていない。

マッピング技術に関しては，写真測量の原理を利用 して，高精度かつ高密度に 3 次元情報を抽出する手法 が従来から行われてきたが，基準点の設置や地物の影 や隠蔽などの撮影条件によっては 3 次元空間デー夕の 自動取得が困難である。そこで対象物の 3 次元情報を 直接自動計測できるレーザスキャ十を用い，マッピン グの効率化や自動化が進为られてきているが, IMUや GPS の技術に依存する割合が多くなるため, マッピン グの精度が IMU や GPS の精度に依存してしまい, 従 来の写真測量技術が有効に利用されていないという問 題点もある(村山ら，2004）。また，GPS は基線解析に より精度良く位置情報を得ることができるが，更新間 隔は 1 秒程度と遅く, 外部依存型のシステムであり, 


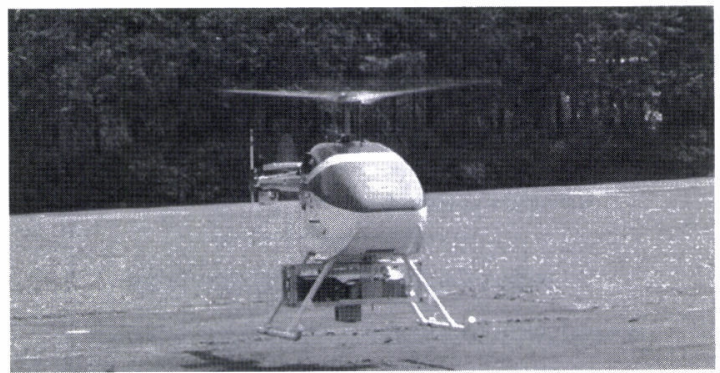

図 1 無地人ヘリコプター（富士重工製：RPH 2）

多くの場合レーザマッピングには利用できない。IMU は外部情報に依存しない自律システムとして, 姿勢の 変化量を計算するジャイロと加速度を検出する加速度 計により位置を計測することができるが，ドリフトエ ラーの影響が大きく，低価格のIMU 単独でのマッピ ングへの利用は難しい（Kumagai ら，2000）。

本研究では, 従来のマッピング技術の利点を共有し, それぞれの欠点を補うマッピングシステムの開発をす
る。センサを統合することにより高精度のマッピング 精度を保ちながらも，民生用デジタルカメラ，低価格 レーザスキャナ，GPS，低価格・中性能 IMU を統合L 利用することで，システム全体の低価格化や小型化を 検討する。特に本研究では計測システムの手軽さ（低 価格化), 機動性 (小型化), 容易さ（自動化）に焦点 を当てた新しいモバイルマッピングシステムの開発を 行う。さらに計測したそれぞれのデー夕を統合し，高 精度のデジタルサーフェスモデルを構築する。また計 測プラットフォームとして無人へリコプターを利用す る(図 1 )。無人へリコプターは, 従来のプラットフォー ムでは困難であった低い高度からの計測を安全かつ容 易に行えると期待される。

\section{2. 計測システムの開発}

本研究では簡便で迅速な計測を目的とするととも に，手軽で機動性のあるシステムを目指す。ゆえに，

表 1 センサの緒元

\begin{tabular}{|c|c|c|c|c|}
\hline & IMU & GPS & レーザスキャナ & デジタルカメラ \\
\hline \multirow{2}{*}{ 機種 } & $\begin{array}{l}\text { TA7544 } \\
\text { （光ファイバージャイロ：FOG） } \\
\text { 多摩川精機社製 }\end{array}$ & $\begin{array}{c}\text { G12 } \\
\text { Ashtech 社製 }\end{array}$ & $\begin{array}{c}\text { LMS291 } \\
\text { SICK 社製 }\end{array}$ & $\begin{array}{c}\text { EOS D60 } \\
\text { キャノン社製 }\end{array}$ \\
\hline & & & 슬 & \\
\hline 特徵 & $\begin{array}{l}\text { FOG は, 高精度ポジョョニングで } \\
\text { 一般的に利用されているリング } \\
\text { レーザジャイロと比較して, 価格, } \\
\text { 性能ともに一桁下のランクに位置 } \\
\text { するが, MEMS (Micro Electro } \\
\text { Mechanical System) 技術の発達 } \\
\text { によ, 小型かつ低価格な中・低 } \\
\text { 精度の IMUが巾場に出ると予測 } \\
\text { れているため(多摩川精機, } \\
\text { 2002), MEMS 型 IMUと同等性 } \\
\text { 能のFOGによるシステム開発は } \\
\text { 意義がある。 }\end{array}$ & $\begin{array}{l}\text { IMUと比べて自立性 } \\
\text { や連続性は低いが, 高 } \\
\text { 精度のデータを取得で } \\
\text { きるようになり, 特に } \\
\text { 航空機やモバイルマッ } \\
\text { ピングの分野では } \\
\text { GPSやIMUは単独 } \\
\text { では使用されない現状 } \\
\text { にある。 }\end{array}$ & $\begin{array}{l}\text { レーザスキャナは対象 } \\
\text { 物の } 3 \text { 次元情報を直接 } \\
\text { 尚動計測でき, その有 } \\
\text { 効性がすでに証明され } \\
\text { ている（趙ら, 2000)。 } \\
\text { 近年の技術進歩に伴 } \\
\text { いレーザスキャナの } \\
\text { 低価格化が進み, 現在 } \\
\text { では数十万円での購大 } \\
\text { が可能になっている。 }\end{array}$ & $\begin{array}{l}\text { 民生用デジタルカメラ } \\
\text { が量産され比較的低価 } \\
\text { 格で購入できるように } \\
\text { なった。すでに民生用 } \\
\text { デシタルカメラを用い } \\
\text { た様々な研究がなさ } \\
\text { れ民生用デジルカ } \\
\text { メを使った写真測量 } \\
\text { への利用の有効性が証 } \\
\text { 明されている(近津ら, } \\
\text { 2001)。 }\end{array}$ \\
\hline 特性 & $\begin{array}{l}\text { 計測範井: } \pm 200^{\circ} / \mathrm{s} \\
\text { 角度 }: \pm 0.1^{\circ} \\
\text { 角速度 : } \pm 0.05^{\circ} / \mathrm{s} \\
\text { 加速度 : } \pm 0.02 \mathrm{~m} / \mathrm{s}^{2}\end{array}$ & $\begin{array}{l}\text { 水平精度 : } 30 \mathrm{~cm} \\
\text { 加速度 : } 20 \mathrm{G} \\
\text { 最大速度 : } 1,000 \mathrm{knts}\end{array}$ & 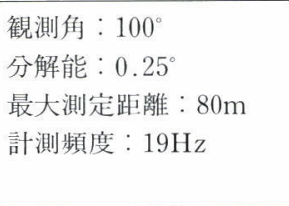 & $\begin{array}{l}\text { 画素数: } 3,072 \times 2,048 \\
\text { 焦点距離： } 24 \mathrm{~mm} \\
\text { シャッター速度 : } \\
\begin{array}{c}1 / 2,000 \text { 秒 } \\
\text { シャッター間隔： } 9 \text { 秒 }\end{array}\end{array}$ \\
\hline 重量 & $1,000 \mathrm{~g}$ & $400 \mathrm{~g}$ & $4,000 \mathrm{~g}$ & $700 \mathrm{~g}$ \\
\hline 価格 & 150 万円 & 40 万円 & 40 万円 & 15万円 \\
\hline
\end{tabular}




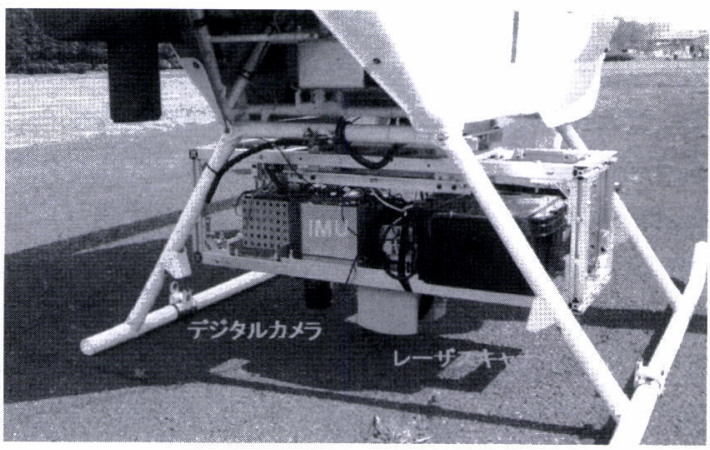

図 2 センサ搭載時の現況写真

従来のような高価なシステムではなく，低価格で小 型・軽量なシステム構成にする。表 1 に本研究で使用 するデジタルカメラ, レーザスキャナ, GPS, IMUの 諸元を示す。これらのセンサは既に市販されおり，容 易に入手することができる。ここでは，これらのセン サの特徴や特性について示す。

本研究では前述したそれぞれのセンサを図 2 に示す ように無人へリコプターの腹部に搭載する。本計測シ ステムでは，2台のノート PC を用い，それぞれの計測 機器を制御するシステムの開発を行い, 計測機器の制 御を行う。GPSの 1 PPS (秒パルス信号) データをそ れぞれのPCに取り入れ，その1 PPSデー夕により， センサの時刻同期を困る。本研究では詳細な時刻同期 を取るために，1/100秒単位で，時刻を合わせている。 さらに，無人へリコプターの腹部に設置したセンサを 強固に固定しているため, 計測の間は常に厳密な位置 と姿勢の関係が保たれている。センサ間の相対的な位 置関係(位置と姿勢) を明確にするためにセンサのキャ リブレーションを行う。また，デジタルカメラにおい ては、レンズの歪みなどが原因となる画像の歪みを補 正するために，あらかじめデジタルカメラの内部標定 を行ってある。

\section{3.センサ統合}

本研究におけるセンサ統合の全体の流れを図 3 に示 す。開発した計測システムによって GPS, IMU，デジ タル画像, レーザレンジ画像が同時に取得できる。こ れらのデータの時刻は同期されており, データ処理は すべて後処理で行われる。初めに GPSの基線解析を 行う。本研究ではWaypoint 社の GrafNavソフトを 使用する。次に基線解析を行った GPSと IMUをカル

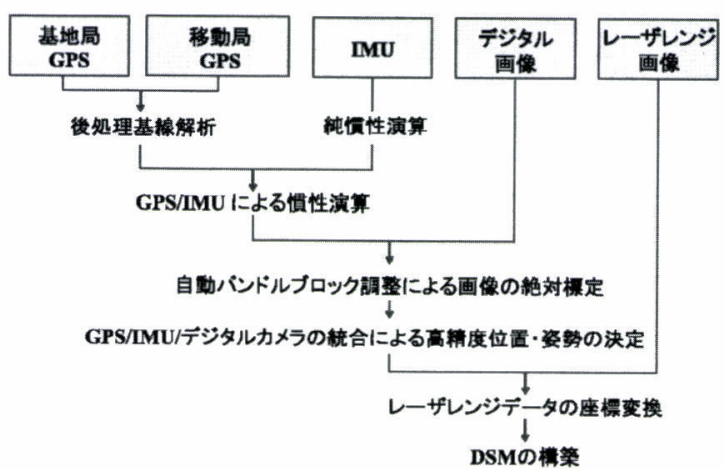

図 3 センサ統合の流れ

マンフィルターで統合する。この GPS/IMU のデータ を用い, 画像のバンドルブロック調整により画像標定 を行い,さらに画像標定の結果をGPS/IMUと統合 し, 高精度の位置・姿勢デー夕を得る。この高精度の 位置・姿勢データを使ってレーザデータの座標変換を 行い, DSM の構築を行う。

\subsection{GPS/IMU による慣性演算}

GPS の後処理基線解析によりセンサの位置を求女 た後で, GPS とIMU を統合するための慣性演算を行 う。GPS/IMUによる慣性演算で求めた位置と姿勢は, 次のステップで行われる画像の絶対標定を行う際の近 似值として利用する。

まず，IMUのみを用いて姿勢，方位，速度，位置を 計算 (純慣性演算) する。四 4 に従った純慣性アルゴ リズムにより慣性演算を行う。ジャイロからの角速度 信号はクォータニオン積算により方向余弦を生成し IMU の姿勢を算出する。それと同時に加速度計の加速 度信号を使って，水平面加速度を算出する。この值を 積分しながらコリオリ補正や重力補正を行い，地球に

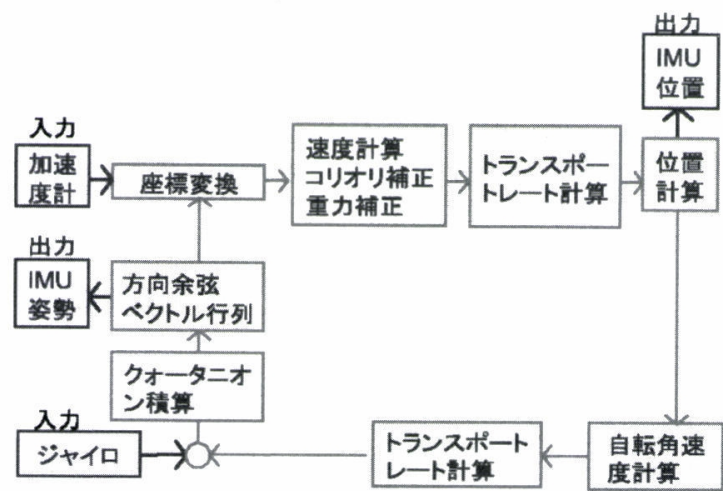

図 4 純慣性アルゴリズム 
対する回転角速度を算出し，初期位置からの移動角度 を求め位置を算出する。位置情報が決定すると自転角 速度成分が計算できるので，実際の角度信号から自転 角速度成分を除去することにより地球座標における位 置の変化を計測することができる(熊谷ら，2002）。今 回の研究で使用した IMU は $200 \mathrm{~Hz}$ でデー夕を取得す るために，これらの計算も $200 \mathrm{~Hz}$ という速い動きに対 して計算することも可能である。

IMU の場合，位置のドリフト（時間的変化）が最大 の問題点である。IMUのドリフトよりも精度の高い GPS の信号を用いて IMU の䛊差を算出し，その誤差 を用いて IMUの各誤差を推定し，誤差がなくなれば 位置精度も向上するので，GPS と IMU の統合は最適 となる。GPS とIMUの統合をするためにカルマン フィルターを用いる。カルマンフィルターに入力され るデータのうち, GPS のデー夕は基線解析が行われた もので, IMU のデー夕は純慣性演算が行われたもので ある。ここで使用するカルマンフィルターは状態推定 フィルターで，観測值 (GPS) から IMU のそれぞれの 誤差を統計的に推定するアルゴリズムである。状態方 程式（式 1）と観測方程式（式 2）により確率システ ムの統計的性質について示す。ここで，Xtは状態べク トル， $Z_{k}$ は観測べクトル， $w_{t}$ と $v_{t}$ は白色雑音ベクト ルとし， $D_{t}, H_{t}$ は行列であり時間 $t$ に依存している。

$X_{t+1}=D_{t} X_{t}+w_{t}$

式 1

$Z_{k}=H_{t} X_{t}+v_{t}$

式 2

$t=0,1, \cdots \cdots$

また本研究では, カルマンフィルターの演算を以下 のステップの繰り返しにより行う。

$\square$ 共分散値の初期化と推定量の初期化

$\square$ GPS 受信状況の把握と観測式の決定

$\square$ 観測值の算出

$\square$ ロルマンゲインの計算

$\square$ 推定量の算出

$\square$ 共分散值の更新

口共分散值の計算

\section{2 自動バンドルブロック調整による画像の絶対標} 定

本研究では, デジタルカメラで撮影された画像をも とに，GPS/IMUの累積されたエラーを補正すること を目的の一つとしている。GPS/IMUを補正するため
に，まずデジタルカメラによって撮影されたデジタル 画像の標定を行い, デジタルカメラの位置と姿勢を算 出する。

本研究では, 大量の画像を効率的に処理するための 自動手法を検討する。自動で画像標定を行うには，あ らかじめ画像間の位置関係が特定されている必要があ るが，本研究では，GPS/IMU の統合による慣性演算 の結果である位置・姿勢を利用し，自動バンドルブロッ ク調整を行う。自動バンドルブロック調整ではバンド ル調整と共面条件を組み合わせた結合調整法を利用す る。結合調整法は地上基準点測量が不要であるために デー夕处理の自動化が可能になる。共面条件では 2 本 の空間直線が同一平面に含まれるという条件が成立す る。IMU/GPS の統合により求められたデジタルカメ ラの位置・姿勢（画像標定の近似值）をもとに，共面 条件から夕イポイントは写真上のエピポラーライン上 にあると仮定する。このエピポラーラインの周りに検 索範囲を指定し，この検索範囲の中で夕イポイントを 検出するための画像マッチングを行い, タイポイント の自動抽出を行う。これらの夕イポイントを用いて, バンドルブロック調整により画像標定を行う。本研究 では， 8 モデル×6コースの絶対標定の同時解を求め る。

\subsection{IMU/GPS/デジタルカメラの統合による高精度 位置・姿勢の決定}

本研究で使用している IMU (FOG) は相対方位角を 検出することはできるが，真方位を検出することはで きない。つまり, 従来の慣性演算では, 計測を行う前 に GPS/IMU のアライメントを行って, 真方位を検出 しなければならない。高精度の IMU では GPS/IMU のアライメントではZUPT 処理 (zero velocity update）を行い，速度が“0”であるという情報をもと に，地球の自転を検出し GPS/IMUの真方位の検出を 行っている。また, 従来の航空測量等で用いられる IMU では，電子コンパスなどにより真方位の検出を し，その情報を GPS/IMUの慣性演算に取り込んでい るが, 十分な精度で真方位を検出するには至らず, 飛 行を開始して速度情報等をもとに，カルマンフィル ターの処理の中で真方位を完全に推定し終わるまでは 精度の良い結果は得られない。

本研究では, 自動バンドルブロック調整により, 高 精度の位置と姿勢を求めることができる。さらに，こ 


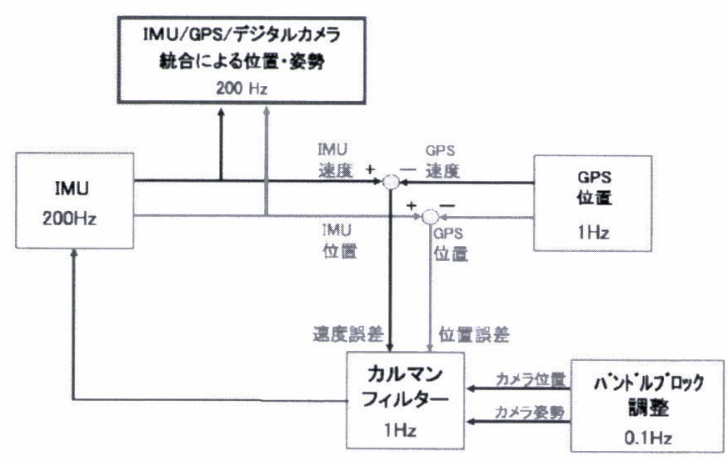

図 5 GPS/IMU/デジタルカメラの統合

の位置と姿勢は絶対標定が行われたものであるので， 真方位が検出されている。本研究では, この自動バン ドルブロック調整により求められたデジタルカメラの 位置と真方位を含む姿勢をカルマンフィルターによる GPS/IMUの慣性演算と統合させる。四 5 に GPS/ $\mathrm{IMU} /$ デジタルカメラの統合の概念困を示す。GPS/ IMUの情報と同様に, 自動バンドルブロック調整の結 果を $0.1 \mathrm{~Hz}$ (デジタルカメラによる画像の取得頻度)で カルマンフィルターに大力され, 位置, 姿勢, 方位が 初期化される。

\section{4 レーザレンジデータの座標変換}

無人へリコプターから計測を行っている間, 搭載さ れたセンサは継続的に動いており，その位置と姿勢を 時間と共に変化させている。計測時のセンサの位置や 姿勢の連続的な変化は IMU/GPS/デジタルカメラを 統合することにより精度よく求めることができる。こ のセンサの位置や姿勢とキャリブレーションにより得 られたそれぞれのセンサ間の相対的な位置・姿勢の関 係により，レーザレンジデータの座標変換を行い 3 次 元モデルの構築を行う。

ヘルマート変換式は回転, 平行移動量, 縮尺を補正 する変換式である。一般的には 2 次元で用いられるこ とが多く, コンパレー夕座標系から指標座標系を求女 る時に用いられる。ここでは，レーザスキャナにより 求められた計測值 (コンパレー夕座標系) を, IMUの 座標 (指標座標系) にヘルマート変換式を用いて変換 する。本研究では式 3 にある 3 次元のへルマート変換 式を利用し 3 次元の座標変換を行う。レーザスキャナ の計測值 $(X 1, Y 1, Z 1)$ を, IMU $(R t, S t)$ を用い て変換する式である。スケールファクター $(s)$, 相詨 姿勢 $(R)$, 相対位置 $(S)$ は, レーザスキャナとデジ

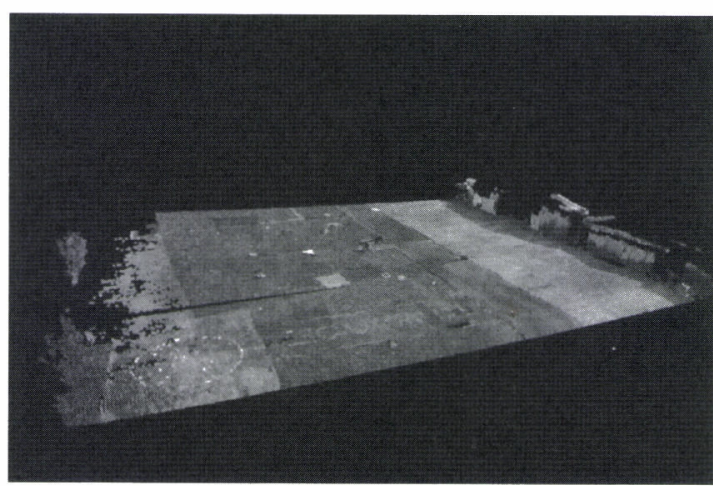

図 6 DSM

タルカメラの相対的な関係で, キャリブレーションに よってあらかじめ求められている。

$\left[\begin{array}{l}X \\ Y \\ Z\end{array}\right]=s \times R \times R_{t} \times\left[\begin{array}{c}\mathrm{X} 1 \\ \mathrm{Y} 1 \\ \mathrm{Z} 1\end{array}\right]+S+S_{t}$

式 3

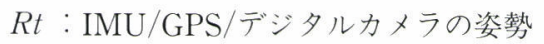

St : IMU/GPS/デジタルカメラの位置

$(X 1, Y 1, Z 1)$ : レーザスキャナ計測值

\subsection{DSM の構築}

式 3 のヘルマート変換式により座標変換されたレー ザレンジデータは絶対座標を持っているが, テクス チャ一情報を持なない点の集まりである。そこで, デ ジタルカラにより取得された画像を用いてレーザレ ンジデータにテクスチャーの情報を貼り付ける。デジ タルカメラにより取得された画像は, バンドルブロッ ク調整により絶対標定が行われている。レーザレンジ データは,この画像のバンドルブロック調整の結果に より補正された IMU/GPS/デジタルカメラの統合結 果を用いてへルマート変換されているために，座標変 換されたレーザレンジデータと絶封標定された画像は 精度良く重なる。网 6 に構築したDSM を示す。

\section{4. 位置・姿勢計測精度の検証}

\section{1 実験の諸元}

無人へリコプターに搭載した計測システムからデー 夕を取得する際には, 高精度の画像標定を行う必要が あり, デジタル画像の撮影範囲や連続する画像のオ一 バーラップ率, デジタルカメラのシャッター間隔をも とに計測速度や撮影高度を決定する。また，撮影高度 
表 2 実験の緒元

\begin{tabular}{|c|c|}
\hline 計測高度 & $50 \mathrm{~m}$ \\
\hline 計測速度 & $1.6 \mathrm{~m} / \mathrm{s}$ \\
\hline 計測範囲 & $\begin{array}{l}80 \mathrm{~m} \text { (進行方向) } \\
\quad \times 90 \mathrm{~m} \text { (幅) }\end{array}$ \\
\hline モデル数 & 8 モデル× 6 コース \\
\hline デジタルカメラ：撮影範囲 & $\begin{aligned} 47.3 \mathrm{~m} （ \text { 進行方向） } \\
\times 31.5 \mathrm{~m} \text { (幅) }\end{aligned}$ \\
\hline デジタルカメラ：地上分解能 & $1.5 \mathrm{~cm}$ \\
\hline オーバーラップ率 & $70 \%$ \\
\hline サイドラップ率 & 50\%（15m 間隔で飛行） \\
\hline レーザスキャナ：スキャン幅 & $120 \mathrm{~m}$ \\
\hline レーザスキャナ：地上分解能 & $30 \mathrm{~cm}$ \\
\hline
\end{tabular}

は,レーザスキャナの最大測定距離も考慮し決定する。 表 2 に実験の諸元を示す。

\section{2 自動バンドル調整}

ここで, GPS/IMUを標定要素の近似值として用い, マッチングによりタイポイントを自動設置した自動バ ンドルブロック調整による絶対標定の精度検証を行 う。この精度検証は, 本研究で提案している絶対標定
の有効性を示すものである。基準点を 8 モデル× 6 コース内に均一に分散して配置し, トータルステー ションにより計測された基準点と, それらの基準点に 対応する自動バンドルブロック調整により求められた 基準点の座標を比較し，その誤差を求めることにより 精度検証を行う。表 3 に自動バンドルブロック調整の 精度検証の結果を示す。この結果によると, X 軸方向 の平面は約 $5 \mathrm{~cm}$ の誤差があり, $\mathrm{Y}$ 軸方向の平面は約 $10 \mathrm{~cm}$ の誤差があり，さらに高さ方向の誤差が約 $16 \mathrm{~cm}$ である。

精度検証は, 従来の基準点を利用し, 手作業で夕イ ポイントを設置したバンドルブロック調整を行い，そ の結果と比較することにより行う。従来の手作業によ る手法では，X 軸方向の平面は約 $1.8 \mathrm{~cm}$ の誤差, $\mathrm{Y}$ 軸 方向の平面は約 $1.6 \mathrm{~cm}$ の誤差，さらに高さ方向の誤差 が約 $14 \mathrm{~cm}$ である。平面方向の誤差が数 $\mathrm{cm}$ 大きくな ク, 自動バンドルブロック調整による絶対標定の方が, 従来手法よりも若干制度が悪いと考えられるが, GPS/IMUによる統合の場合，精度はGPSの精度に 依存するとされ(多摩川精機，2002)，GPS/IMUによ る統合の精度 $($ 約 $30 \mathrm{~cm})$ と比較すると，自動バンドル ブロック調整により得られた精度は GPS/IMUを補

\section{表 3 自動バンドルブロック調整の精度検証}

\begin{tabular}{|c|c|c|c|c|c|c|c|c|c|}
\hline & & & & & & & & & \\
\hline $\begin{array}{l}\text { 基準点 } \\
\text { No. }\end{array}$ & $\begin{array}{c}\text { 基準点 } \\
(\mathrm{X})\end{array}$ & $\begin{array}{l}\text { 基準点 } \\
(\mathrm{Y})\end{array}$ & $\begin{array}{l}\text { 基準点 } \\
\text { (h) }\end{array}$ & $\begin{array}{c}\text { 自動バンドル } \\
\text { 調整 }(\mathrm{X})\end{array}$ & $\begin{array}{c}\text { 自動バンドル } \\
\text { 調整 }(\mathrm{Y})\end{array}$ & $\begin{array}{c}\text { 自動バンドル } \\
\text { 調整 (h) }\end{array}$ & $\begin{array}{c}\text { 誤差 } \\
(\mathrm{X})\end{array}$ & $\begin{array}{c}\text { 誤差 } \\
(\mathrm{Y})\end{array}$ & $\begin{array}{l}\text { 誤差 } \\
(\mathrm{h})\end{array}$ \\
\hline 1 & -11193.977 & -25634.338 & 43.197 & -11193.956 & -25634.337 & 42.733 & 0.021 & 0.001 & 0.464 \\
\hline 2 & -11183.018 & -25637.129 & 42.903 & -11183.056 & -25637.161 & 42.944 & 0.038 & 0.032 & 0.141 \\
\hline 3 & -11173.826 & -25639.645 & 42.849 & -11173.883 & -25639.719 & 42.954 & 0.057 & 0.074 & 0.105 \\
\hline 4 & -11162.471 & -25642.662 & 42.788 & -11162.535 & -25642.784 & 42.905 & 0.064 & 0.122 & 0.117 \\
\hline 5 & -11149.337 & -25646.23 & 42.747 & -11149.406 & -25646.415 & 42.705 & 0.069 & 0.185 & 0.142 \\
\hline 6 & -11191.888 & -25626.436 & 43.158 & -11191.843 & -25626.47 & 42.859 & 0.045 & 0.034 & 0.299 \\
\hline 7 & -11181.053 & -25629.473 & 42.979 & -11181.053 & -25629.54 & 43.047 & 0 & 0.067 & 0.068 \\
\hline 8 & -11172.17 & -25631.944 & 42.91 & -11172.182 & -25632.035 & 43.005 & 0.012 & 0.091 & 0.095 \\
\hline 9 & -11162.446 & -25634.822 & 42.798 & -11162.468 & -25634.95 & 43.049 & 0.022 & 0.128 & 0.251 \\
\hline 10 & -11146.794 & -25638.299 & 42.83 & -11146.809 & -25638.474 & 42.744 & 0.015 & 0.175 & 0.086 \\
\hline 11 & -11189.846 & -25619.937 & 43.14 & -11189.763 & -25619.982 & 42.98 & 0.083 & 0.045 & 0.16 \\
\hline 12 & -11178.933 & -25622.631 & 42.983 & -11178.887 & -25622.693 & 43.179 & 0.046 & 0.062 & 0.196 \\
\hline 13 & -11170.569 & -25624.923 & 42.924 & -11170.543 & -25625.013 & 43.097 & 0.026 & 0.09 & 0.173 \\
\hline 14 & -11160.683 & -25626.974 & 42.895 & -11160.647 & -25627.106 & 43.06 & 0.036 & 0.132 & 0.165 \\
\hline 15 & -11145.225 & -25630.81 & 42.868 & -11145.199 & -25631.005 & 42.861 & 0.026 & 0.195 & 0.007 \\
\hline 16 & -11187.676 & -25611.033 & 43.146 & -11187.555 & -25611.076 & 43.114 & 0.121 & 0.043 & 0.132 \\
\hline 17 & -11176.563 & -25614.229 & 43.063 & -11176.473 & -25614.312 & 43.209 & 0.09 & 0.083 & 0.146 \\
\hline 18 & -11168.23 & -25616.687 & 42.989 & -11168.144 & -25616.783 & 43.15 & 0.086 & 0.096 & 0.161 \\
\hline 19 & -11159.017 & -25619.338 & 42.908 & -11158.942 & -25619.456 & 43.132 & 0.075 & 0.118 & 0.224 \\
\hline 20 & -11143.597 & -25623.954 & 42.879 & -11143.52 & -25624.128 & 42.912 & 0.077 & 0.174 & 0.133 \\
\hline & & & & & & 匀誤差 0 & & 99735 & \\
\hline
\end{tabular}


正するには十分な精度であると考えられる。

\subsection{GPS/IMU/デジタルカメラの統合による位置・姿 勢演算の結果}

図 7 に IMU, GPS, デジタルカメラを統合したセン サの軌跡を示す。カルマンフィルターを用いて GPS/ $\mathrm{IMU} /$ デジタルカメラは統合され, $200 \mathrm{~Hz}$ の位置と姿 勢として出力される。従来の GPS/IMUのみの統合で は, 統合後の精度は GPS に依存するが, IMU/GPS/デ ジタルカメラ統合の場合, 統合後の精度は画像の絶対 標定の精度に依存すると考之られる。画像の絶対標定 の精度検証の結果から, 地上座標の精度は $5 \mathrm{~cm}$ から $10 \mathrm{~cm}$ であるので, センサの姿勢角精度は 0.0013 から $0.0025^{\circ}$ になる。つまり, 中精度の光ファイバージャイ 口を使用しているにもかかわらず，高価格なリング レーザジャイロと同等の姿勢角精度を得ることができ る。

ここで, デジタルカメラによって撮影された画像の 標定結果をカルマンフィルターに入力する GPS/ IMU/デジタルカメラを統合した慣性演算の結果と,

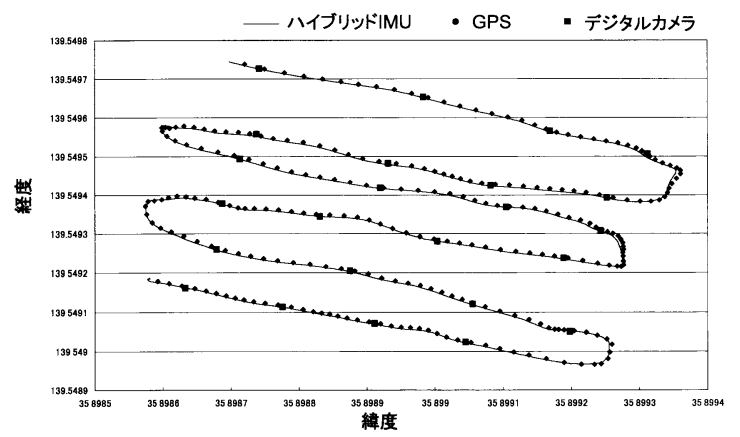

图 7 IMU/GPS/デジタルカメラの軌跡

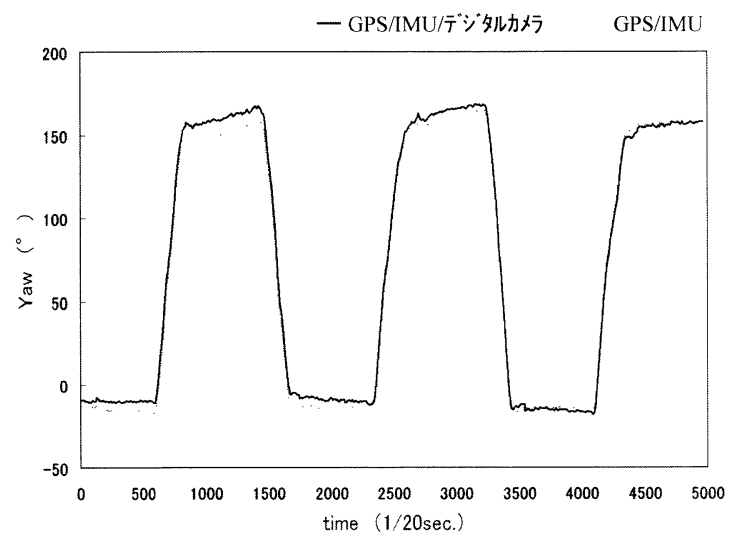

図 8 方位角の比較
従来の GPS/IMU のみによる慣性演算の結果を比較 し，ポジショニングの精度や方位角精度等，本手法の 有効性について確認する。

図 8 に方位角を比較した図を示す。実線がGPS/ IMU/デジタルカメラ，破線がGPS/IMUによる慣性 演算を行った結果の方位角変化をそれぞれ示す。 GPS/IMU/デジタルカメラでは, 画像標定による正確 な方位角が入力されるので，計測を開始した時点から 高精度の方位角が決定できる。一方，GPS/IMUによ る慣性演算では，計測を始めて徐々に方位角の精度が 高くなっていき,最終的に GPS/IMU/デジタルカメラ の慣性演算による方位角と重なる。GPS/IMU の統合 によるカルマンフィルターによる状態推定では，徐々 に精度が上がる特徵がある。よって，本研究で提案し た GPS/IMU/デジタルカメラの統合し, 画像標定の結 果を入力することにより，高精度の方位角が計測開始 直後から得ることができる。図 9 にロール角の比較, 困10にPitch 角の比較を示す。方位角と同様に, 図 9 と

$$
\text { — GPS/IMU/デジタルかメラ GPS/IMU }
$$

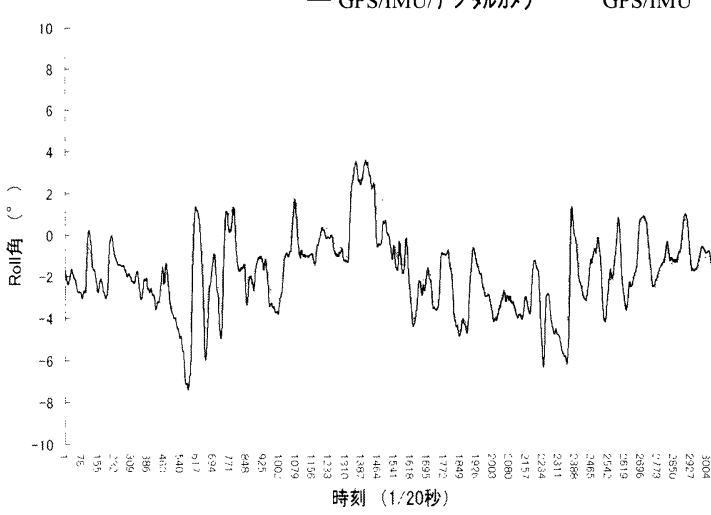

図 9 Roll 角の比較

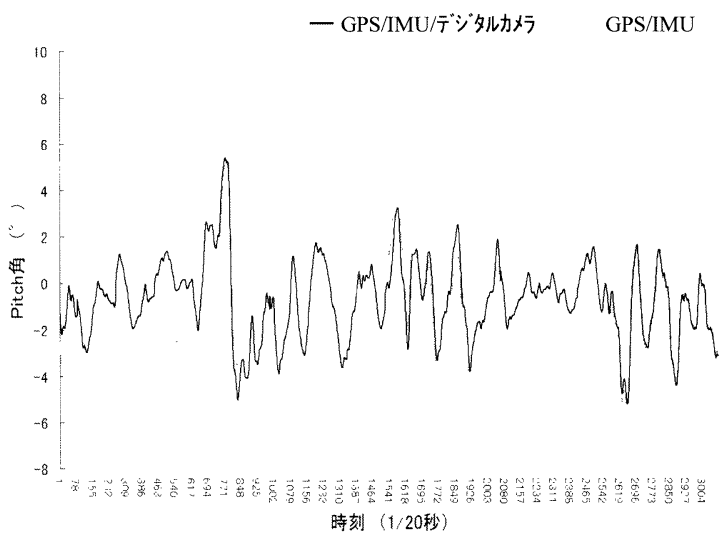

図10 Pitch 角の比較 


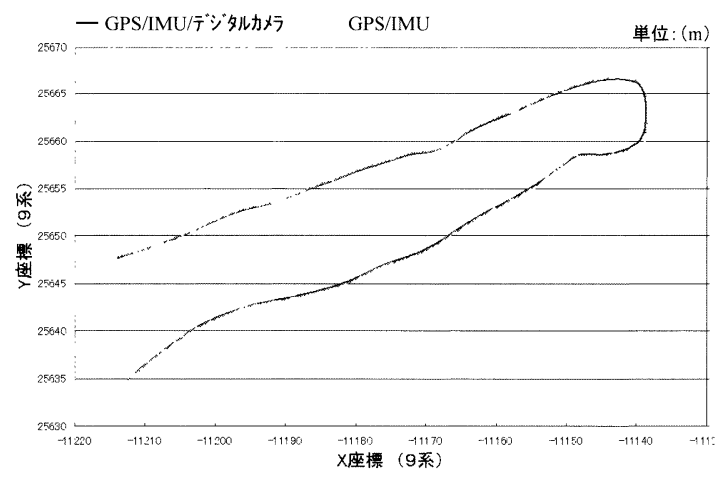

図11 軌跡の比較

四10においても, 本研究で提案する GPS/IMU/デジ夕 ルカメラの統合により, 計測開始直後から精度の良い 情報を得ることができる。従来の手法では, 計測を行 う前にアライメントを行い，方位角等のセンサの初期 姿勢を決定するが，前述した様に高精度の結果を計測 開始直後から得ることは難しい。本手法により，これ らの手間を省くことができる。

次ぎに, 四11にフライトの軌跡を比較した困を示す。 座標系は日本测地系の 9 系である。実線が GPS/IMU/ デジタルカメラ, 破線が GPS/IMUによる慣性演算を 行った結果の位置を示したものである。GPS/IMUの 統合では，アライメントを行いカルマンフィルターに よる状態推定を何度も行って精度の良い姿勢角が決定 されるまでは, IMUのドリフトが完全に補正されない ので, カルマンフィルターでGPSによる位置補正を 行った際に，位置が強制的に修正されるために，セン サの軌跡がギザギザになる。特に急旋回を行った場合
には顕著である。一方，GPS/IMU/デジタルカメラの 統合では，精度の良い姿勢角が画像標定により特定で きるので，カルマンフィルターにより，より精度の高 い状態の推定ができる。そのために，強制的に位置が 修正されることが少なく滑らかなセンサの軌跡にな る。

\subsection{DSM の精度検証}

ここでは, 構築したDSM の精度検証を行う。本計測 システムは, IMU, GPS, デジタルカメラ, レーザス キャナを統合することにより，いくつもの要素技術が 絡み合って構成されているため, 構築した DSMの精 度は，それぞれの計測機器の誤差を複合させることに よるもので，センサ統合後のそれぞれの計測機器の精 度を検証することは大変困難である。そこで本研究で は，測量方法の精度を議論する方法を用いて精度検証 を行う。地上基準点や特徵的な地物などを利用し，構 築したDSMよりも精度が良いと考えられる基準点を 利用したバンドルブロック調整の結果を実測値とし， これと比較することにより構築された DSM の精度を 検証する。自動バンドルブロック調整による画像の精 度検証は，すでに証明されているので，ここでは主に DSM の精度について検証を行う。

精度検証を行うにあたり，画像とDSM から識別す ることのできる特徵点を数点抽出する。特徵点は, 地 物の角等を利用し，色だけでなく，3 次元形状からも 識別可能な点を選ぶ。その特徵点について，地上基準 点を利用したバンドルブロック調整による画像標定の 結果と，DSM から抽出された基準点の座標を比較す

表 4 DSM の精度

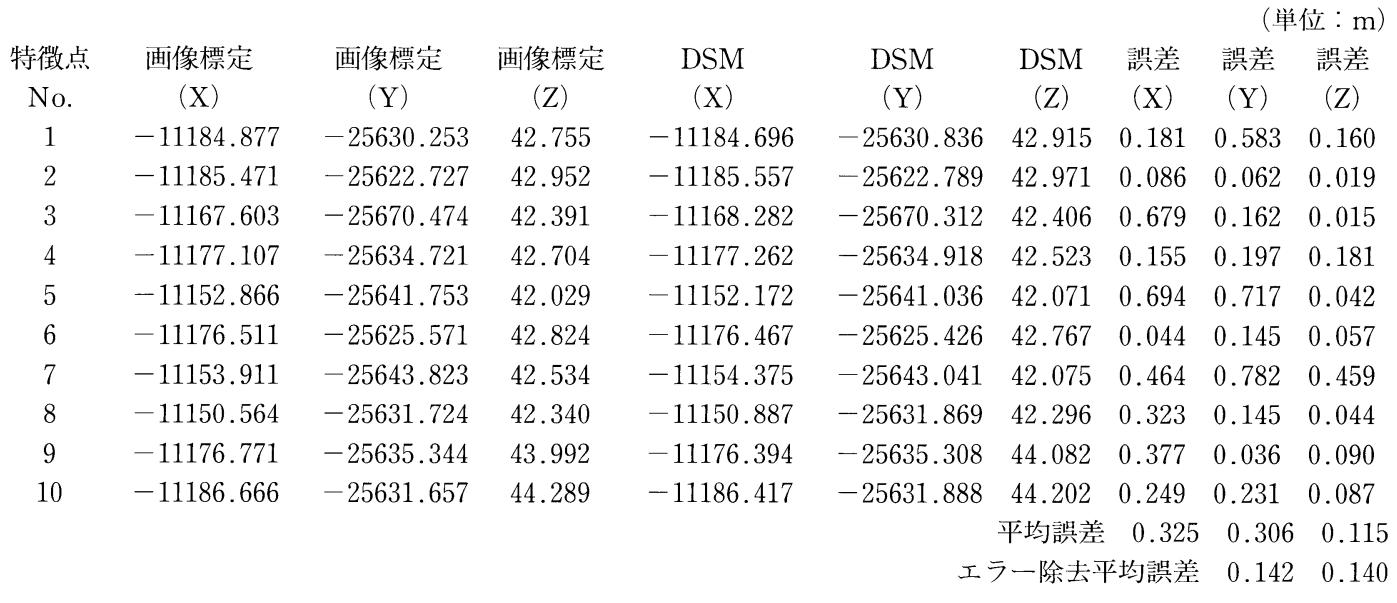


ることにより精度検証を行う。表 4 にDSMの精度検 証結果を示す。10点の特徽点を抽出し, これらの位置 䛊差を算出した結果, $10 \mathrm{~cm}$ から $30 \mathrm{~cm}$ の位置精度で DSM が構築されていることが確認できる。また, 特徵 点No.1，3，5，7については, 他の䛊差と比較して 大きな值が出ている。この值は, DSM の特徽点を抽出 する際の抽出エラーに起因すると考之られる。レーザ レンジデータの分解能はおよそ $30 \mathrm{~cm}$ であるが, 特徽 点を決定する際にレンジ画像の角度により複数の点が 重なり，その際に抽出エラ一があったと考之られる。 そこで, これらのエラ一值を除き, 再度精度検証老行 うと, $\mathrm{X}-\mathrm{Y}$ 平面で $14 \mathrm{~cm}$, 高さ方向で $8 \mathrm{~cm}$ と高精度の マッピングができたことが証明できる。

\section{5.データ統合利用}

\section{1 レーザ補助による画像ステレオマッチング}

従来から広く利用されている手法であるステレオ マッチングを, さらに効果的に精度良く自動で行うた めに、レーザレンジデー夕を利用する。前項でDSMを 構築する際に, 本研究で取得したレーザレンジデー夕 とデジタル画像は精度良く重なっていることを述べて

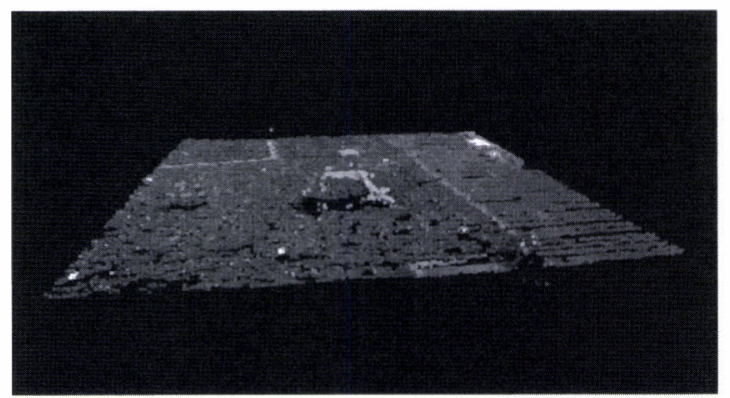

図12 レーザ補助による画像ステレオマッチング

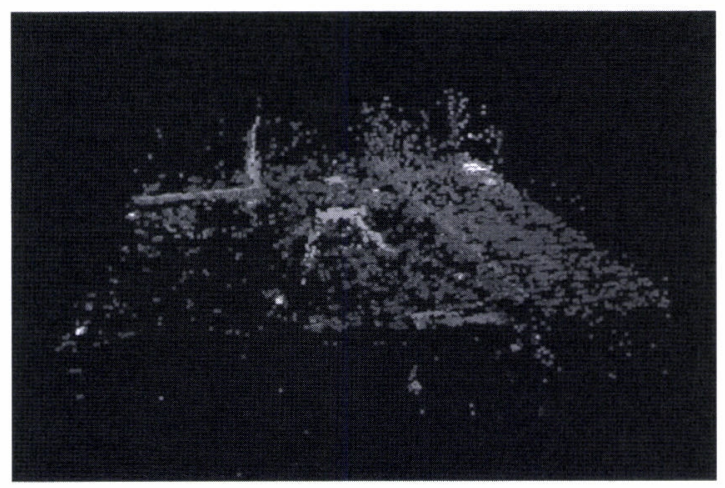

図13 従来の画像ステレオマッチング
いる。ここでは, 画像のステレオマッチングを行う際 に, レーザレンジデータの高さ情報（概要形状）を利 用する。1 組のステレオ画像で, 左画像の“ある” ピ クセルに対して, 右画像から対応する点を従来通り画 像相関の計算から自動的に検出するのであるが，その 時に，そのピクセルに対応しているレーザレンジデー 夕の高さ情報を利用して, 右画像の対応点の検索範囲 を定義する。レーザレンジデータにより検索範囲を絞 $\eta$, その検索範囲の中から対応点を決め, ステレオマッ チングを行う。この手法により，ミスマッチングを格 段に減らせることが可能になる。四12にレーザレンジ データを利用してステレオマッチングを行ったDSM を示す。四13に示す従来のステレオマッチングと比較 して, ミスマッチングに起因する 3 次元モデルのノイ ズがほとんど存在しないことが容易に分かる。レーザ レンジデータは密度が低いので, より高密度の DSM の構築を必要とする場合には, 非常に有効的な手法で ある。

\section{2 レーザレンジ画像の内挿}

レーザレンジデータは対象物との距離を直接計測す るために，複雑な形状を効率良く計测することができ るという利点を有している。しかし, 前述しているよ うにレーザスキャナはラインセンサであり，レーザレ ンジデー夕の分解能は $10 \mathrm{~cm} \sim 20 \mathrm{~cm}$ であるが，搭載す るプラットフォームのスピードや姿勢の急激な変化が 原因となり，レーザレンジ画像は図14(a)に示すように 吵間ができてしまうことがある。一方, デジタルカメ ラ(図14(b)) はエリアセンサによって撮影し, 地上分 解能が $1 \mathrm{~cm}$ 1.5 cm ほどであるために, 隙間なく情報 が得られる。四14(a)，(b)からも分かるように、レーザ レンジ画像とデジタル画像のデータ密度の差は明らか である。そこでデジタル画像を用い, レーザレンジ画

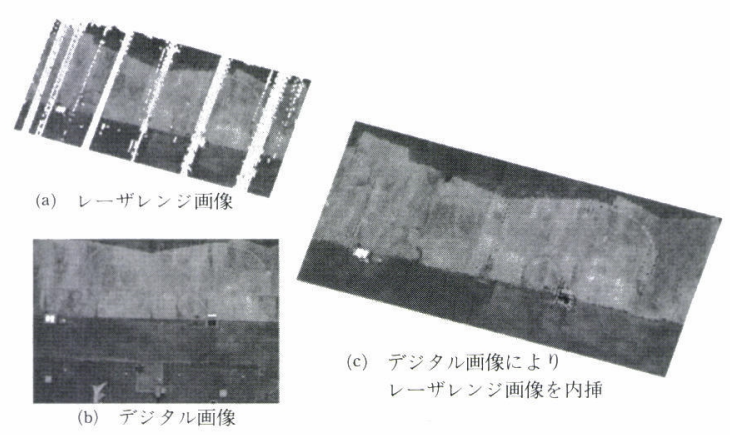

図14 レーザレンジ画像の内挿 
像の隙間を補間するための内挿を行い, 図14(c)に示す 通り，画像による補完でレーザレンジデータを内挿す ることができる。

\section{3 地物抽出}

構築されたDSM を利用して, 詳細な地物の抽出を 行う。従来の人工衛星や航空機からの 3 次元計測では 不可能であった詳細な地物の抽出を, 高分解能デー夕 を用いることにより容易に行えるようになる。また， DSM と同時にデジタル画像も存在するために, レー ザレンジデータから複雑な形状を求め, 詳細なテクス チャーの情報はデジタル画像から,さらにデータの補 間を行う等，それぞれの利点を利用することで，効率 的に詳細な地物の抽出を行うことができる。

\section{6. 結 論}

本研究では，様々なセンサを統合することにより， 低価格，高機動性，高精度計測を実現できるマッピン グシステムを開発した。民生用デジタルカメラ, 低価 格レーザスキャナ, GPS, 低価格・中性能 IMUを統合 することにより, 個々のセンサは低価格・低性能では あるが, それぞれのセンサの利点を共有し, 弱点を補 うことのできる新規 3 次元マッピングシステムであ る。また計測プラットフォームは無人へリコプターを 利用した。無人へリコプターは, 従来のプラットフォー ムでは困難であった低い高度からの計測を安全かつ容 易に行うことができる。

複数のセンサを統合することにより, 画像標定の自 動化, 高精度慣性演算の実現, DSM の自動構築, 画像 ステレオマッチングの高精度自動化, 取得デー夕の補 完, さらには地物の自動抽出に至るまで, 従来の単独 センサでは困難であった処理を可能にした。

本論文は安価で小型なセンサを統合する手法を開発
し, 実際に機動性に優れ, 低価格で高精度な 3 次元デー 夕取得システムが構築できることを実証的に明らかに している。この統合センサシステムは沉用性も高く, さまざまなプラットフォームに搭載され，歩行者ナビ 用の地下街地圀から災害調查まで幅広く利用すること が可能である。

(受付日2005.6.8, 受理日2005.11.18)

\section{参考文献}

趙 卉蕫, 柴崎亮介, 2002, 車載型レーザレンジデー 夕による 3 次元都市空間モデルの構築，第 8 回画像 センシングシンポジウム。

村山盛行，佐田達典，2004，地上レーザスキャナと

GPS/IMUを用いた三次元形状計測システムの開 発，応用測量論文集，Vol. 15，pp.91-102.

Kuamgai, H., Kindo, T., Kubo, Y., Sugimoto, S., 2000. DGPS/INS/VMS Integration for High Accuracy Land-Vehicle Positioning, Proceedings of the Institute of Navigation, ION GPS-2000, Salt Lake.

多摩川精機㑣偏，2002，ジャイロ活用技術入門，工業 調查会.

趙 卉菩, 柴崎亮介, 2000, 地上据え置き型レーザレ ンジスキャナを利用した 3 次元都市空間データの自 動構築手法に関する研究, 写真測量とリモートセン シング, Vol.39, no. 2, pp.48-51.

近津博文, 国井洋一, 中田隆司, 2001, デジタル写真 測量からみた 300 万画素デジタルスチルカメラの精 度検証，写真測量とリモートセンシング，Vol. 40, no. 2 , pp.22-38.

熊谷秀夫, 久保幸弘, 木原正人, 杉本未雄, 2002, DGPS/ INS/VMS を統合した高精度車両位置計測アルゴ リズム，写真測量とリモートセンシング. Vol. 41, No. 4 , pp.77-84. 